Chapman University

Chapman University Digital Commons

Philosophy Faculty Articles and Research

Philosophy

1975

\title{
John Locke in the German Enlightenment: An Interpretation
}

Klaus P. Fischer

Chapman University

Follow this and additional works at: http://digitalcommons.chapman.edu/philosophy_articles

Part of the Ethics and Political Philosophy Commons, History of Philosophy Commons, and the Philosophy of Mind Commons

\section{Recommended Citation}

Fischer, Klaus P. "John Locke in the German enlightenment: an interpretation." Journal of the History of Ideas (1975): 431-446. DOI: $10.2307 / 2708655$

This Article is brought to you for free and open access by the Philosophy at Chapman University Digital Commons. It has been accepted for inclusion in Philosophy Faculty Articles and Research by an authorized administrator of Chapman University Digital Commons. For more information, please contact laughtin@chapman.edu. 


\section{John Locke in the German Enlightenment: An Interpretation}

\section{Comments}

This article was originally published in Journal of the History of Ideas in 1975. DOI: 10.2307/2708655

\section{Copyright}

University of Pennsylvania Press

This article is available at Chapman University Digital Commons: http://digitalcommons.chapman.edu/philosophy_articles/1 


\section{JOHN LOCKE IN THE GERMAN ENLIGHTENMENT: AN INTERPRETATION}

\section{By Klaus P. Fischer}

I. A favorite assumption of Anglo-American scholarship, endlessly repeated in textbooks and monographs, is that Locke's philosophy triumphed in every nook and cranny of Western Europe. By implication, it is also assumed that other philosophic systems, especially those of Descartes and Leibniz, withered away without much opposition. The reigning philosophy of the Enlightenment, we are told, was that of Locke and his disciples in England and on the Continent. Some have gone so far as to claim that Locke's "influence pervades the eighteenth century with an almost scriptural authority."

Examining the philosophic traditions of individual nations in eighteenth-century Europe, one encounters a slightly different picture. Taking the German Enlightenment as an example, this essay is meant to dispute, if not destroy, the exaggerated importance ascribed to John Locke in eighteenth-century Europe.

In France Locke faced the formidable Cartesian system; in Germany he encountered an almost insurmountable obstacle in the Leibniz-Wolff school. ${ }^{2}$ It has been observed that in Gottfried Wilhelm Leibniz (1646-1716) the Germans had a Newton and a Locke rolled into one - that is to say, Leibniz was at once a great scientist and a philosopher. ${ }^{3} \mathrm{He}$ was the father of German philosophy as surely as Descartes was the founder of French philosophy. He was not only a perpetuum mobile of science, but the true preceptor of the German nation. Every foreign philosophy, therefore, had to reckon with the authority of Leibniz, and after his death with that of Christian Wolff (1679-1754), who endowed Leibniz's thought with the esprit de système. The LeibnizWolff school exercised an almost iron grip on German philosophy from $1680-1750 .^{4}$ This success was due, in large part, to Wolff's pedagogic skill in systematizing Leibnizian doctrines; in doing this, Wolff at once satisfied the deep urge of the German mind for order and the scholastic

${ }^{1}$ Alfred Cobban, Edmund Burke and the Revolt against the Eighteenth Century (New York, 1929), 16.

${ }^{2}$ Aram Vartanian, in his brilliant work, Diderot and Descartes, has demonstrated the persistent influence of Descartes in the French Enlightenment. Much credit is due him for modifying the exaggerated view of Locke's importance in eighteenth-century France.

${ }^{3}$ A. Wolfstieg, "Englischer und Französischer Deismus und die Deutsche Aufklärung," Monatshefte der Comenius-Gesellschaft, 17 (May 1908), 145.

${ }^{4}$ For the triumph of the Wolffians in the German universities: Max Wundt, Die deutsche Schulphilosophie im Zeitalter der Aufklärung (Tübingen, 1945). 
tenor of German philosophy. The results were amazing: Wolff's fame spread like wildfire and his disciples captured most university positions in Germany. According to one source, there were 231 literary figures in 1738 who officially acknowledged Wolff as their preceptor. ${ }^{5}$

Wolff expounded an abstract rationalism that soon pervaded other fields besides philosophy. The literary counterpart to Wolff, for example, was Johann Christoph Gottsched (1700-66), whose influence equalled-perhaps even surpassed-that of Wolff. Not until both men passed from the scene in the late 1750's could any rival mode of thought hope to win the allegiance of German philosophers or men of letters.

There was, of course, some opposition to Wolffianism during its hegemony from 1720-50. This opposition emanated from Christian Thomasius (1655-1728) and his followers. Thomasius developed an empirical theory of knowledge loosely similar to that of Locke. This resemblance has caused considerable speculation about Thomasius' indebtedness to his English counterpart. ${ }^{6}$ Since both thinkers wrote at about the same time, this question of "influence" may never be sett!ed conclusively. One fact, however, seems fairly certain: Locke's common sense temper, especially in religion, seems to have prompted Thomasius to return to his earlier position of secular empiricism-a position from which he had been temporarily deflected by Pietism. ${ }^{7}$ Thomasius always spoke approvingly of Locke's philosophy, whose secular and empirical tenor reinforced his own philosophic outlook. He was by nature a rebellious spirit, eager to eradicate the remnants of scholasticism and to provide knowledge with a purely secular and empirical basis. In practice, however, he was not able to remove all the vestiges of tradition; and, like Luther's, his reforming spirit often veiled a stubborn streak of conservatism. This was most apparent in his moral philosophy, radically different from Locke's eudaemonistic-utilitarian ethics. It is well to recall that Thomasius lived in a different social milieu than Locke's. German thinkers, bound by encrusted medieval socio-economic conditions, still accepted moral values which the English had already outgrown: avoidance of risks and excessive profits, rejection of competition and self-advancement, and abstention from social or political aspirations. A parade of German moralists, including

${ }^{5}$ Quoted by Carl Justi, Winckelmann und seine Zeitgenossen (Leipzig, 1923), I, 78.

${ }^{6}$ The similarity between Thomasius and Locke is noted briefly by Walter Bienert, Die Philosophie des Christian Thomasius (Halle, 1934), 11; Cay von Brockdorff, Die Deutsche Aufklärungs-Philosophie (Munich, 1926), 42; Gustav Zart, Einfluss der englischen Philosophen seit Bacon auf die deutsche Philosophie des 18. Jahrhunderts (Berlin, 1881), Pt. 3, Ch. 1; Max Wundt, Die deutsche Schulphilosophie im Zeitalter der Aufklärung (Tübingen, 1945), 31-32; and Erik Wolf, Grosse Rechtsdenker der deutschen Geistesgeschichte (Tübingen, 1939), 329.

'Thomasius' return to a more temperate and rationalistic religion came after he read Locke's chapter on "Enthusiasm" (IV, 19), added to the fourth edition of the Essay Concerning Human Understanding (1700). 
Thomasius, continued to propound ethical systems based on altruistic love, stoic isolation, and psychological quietude. ${ }^{8}$

Brought up in a backward social environment characterized by religious superstition, political repression, and economic stagnation, Thomasius could not be expected to embrace modernity in quite the same way in which his English counterpart Locke pursued it. His moral and political ideas, reflecting German conditions, differ markedly from those of Locke. In his political philosophy, for example, Thomasius was a proponent of "enlightened absolutism." The ideal of constitutional government, which he thought incompatible with man's corrupt nature, he classified under "sick forms of government."9

It would be misleading, however, to single out the traditionalism of German society as the only obstacle to Lockean ideas. Thomasius was not the best spokesman for Locke's philosophy. He was by profession a jurist and pursued philosophical problems only as an avocation. His philosophical treatises were little more than practical manuals, designed to turn young gentlemen into civilized human beings. Compared to Wolff's imposing tomes, the works of Thomasius appear pathetically slender. In place of magnificent categories, divisions, and subdivisions, Thomasius offered a few common sense maxims (Handgriffe). In choosing this popular manner of exposition, he committed a serious tactical error: by side-stepping all philosophical complexities, he lost his opportunity to establish an academic tradition that might have been able to compete with the reigning school of abstract rationalism. As it was, his empiricism hardly made a ripple in the vast sea of German rationalism. In eighteenth-century Germany, we must remember, the success or failure of a philosophic system depended largely on three factors: the influence of its author in the academic community, the manner of its exposition, and the quality of its disciples. Thomasius' philosophy failed on all three counts. The academic world, still thoroughly scholastic and traditional, regarded him as a bete noire because he had nothing but contempt for its traditional assumptions. ${ }^{10}$ His popular and eclectic treatment of ideas was also bound to be ineffective in a scholarly community which prized the "spirit of thoroughness" (Geist der Gründlichkeit, as Kant called it). As to Thomasius' followers, they were epigoni, who exercised little influence on German thought. Thomasius' students generally swelled the ranks of the obedient civil servants and became cautious legalists. Only a few followers of Thomasius, such as Johann Franz Buddeus (1667-1729),

${ }^{8}$ The best treatment of this moral dimension in the German Enlightenment may be found in Hans M. Wolff, Die Weltanschauung der deutschen Aufklärung in Geschichtlicher Entwicklung (Berne, 1963).

${ }^{9}$ For a fine discussion of Thomasius' political philosopl $\rightarrow$ F. M. Barnard, "The Practical Philosophy of Christian Thomasius," JHI, 32 (April-June 1971), 221-46.

${ }^{10}$ Walter Bienert (Die Philosophie des Christian Thomasius, 74) observes that an “icy silence" descended upon Thomasius' thought after his death. 
Nicholaus Hieronymus Gundling (1671-1729), Andreas Rüdiger (16731731), and Christian August Crusius (1715-75), pursued an academic career. These men, however, were utterly ineffective in stemming the tide of Wolffianism. In spite of some efforts to combat Wolffianism, the number of the Thomasians declined as that of the Wolffians rose. By 1740, at the height of Wolff's power, the Thomasians have practically disappeared and their textbooks have been forgotten. ${ }^{11}$

It was among the Thomasians, then, that Lockean ideas were for the first time seriously studied in Germany. The weakness of the Thomasian opposition to Wolff, however, made it very difficult for Locke to get a fair hearing. Locke's first appearance in Germany, therefore, passed largely unnoticed. From 1704 to 1754 (from the death of Locke to the death of Wolff) Locke was a quiet subterranean force in German philosophy, overshadowed by the Leibniz-Wolff school.

II. In the 1740's and 1750's the rationalistic systems of Wolff and Gottsched experienced their first setbacks. Under the influence of Pietism, English empiricism, and middle-class sentimentality (Empfindsamkeit), latent dissatisfaction with abstract rationalism now broke out into the open. The rationalistic mode of thought was challenged from several points of view by Germany's poets, philosophers, and artists.

The first, and perhaps the most serious, attack against Wolff took place within the Berlin Academy. ${ }^{12}$ Founded by Leibniz, who also served as its first president, the Berlin Academy had reached the heights of prestige and effectiveness under Frederick the Great. From the beginning, Frederick hoped that the Wolffians and Newtonians could be made to cooperate within the Academy. ${ }^{13} \mathrm{He}$ was sadly disappointed. When the famous French scientist Pierre-Louis Moreau de Maupertuis (1698-1759), a Newtonian and a sworn enemy of Wolff, became president of the Academy the battle between English philosophy and German philosophy was joined. On the Newtonian (Lockean) side were ranged Maupertuis, Leonhard Euler (1707-83), and Johann Heinrich Lambert (1728-77); on the Wolffian side the most important men were George Sulzer (1720-79), Samuel Formey (1711-97), and Johann Philipp Heinius (d. 1775). ${ }^{14}$

\footnotetext{
${ }^{11}$ Gustav Zart, Einfluss der englischen Philosophen seit Bacon auf die deutsche Philosophie des 18. Jahrhunderts (Berlin, 1881), 60.

${ }^{12}$ For an excellent account of the prolonged and bitter controversy between the Wolffians and the Newtonians in the Berlin Academy: Adolf Harnack, Geschichte der Königlich Preussischen Akademie der Wissenschaften zu Berlin, Vol. I, Bk. 2, Ch. 2 (Berlin, 1900). There is also a fine article on the Newton-Wolff controversy $\rightarrow$ Ronald S. Calinger, "The Newtonian-Wolffian controversy, 1740-1759," JHI, 30 (July-Sept. 1969), 319-30.

${ }^{13}$ Adolf Harnack, Geschichte der Königlich Preussischen Akademie, I, 254.

${ }^{14}$ Though Euler and Lambert were ranged on the Newtonian side, it must not be inferred from this that they were also Lockeans. Both men displayed a readiness to ap-
} 
The year 1747 marked the opening engagement. In that year, the Academy posed, as the subject of its annual prize essay, the question whether monads had a foundation in reality. ${ }^{15}$ The decision went against Wolff when the first prize was awarded to a relatively unknown legal scholar, who had delivered a scathing critique of monads. A much more serious battle, this time involving the prestige of Leibniz himself, broke out in 1751. The chief protagonists were Samuel König, a leading Dutch mathematician, and Maupertuis. König submitted a manuscript in which he criticized the "Principe de la moindre action," a principle Maupertuis claimed to have discovered. Not only did König prove that Maupertuis' principle-as he stated it-was erroneous, but also that Leibniz had already discovered the correct principle. It was especially the assertion that he had been anticipated by Leibniz that infuriated Maupertuis, and he demanded documentation. König, however, possessed only a copy of Leibniz's statement and was unable to produce the original. The Academy, asked to judge the case, took Maupertuis' side, declaring König's copied letter a forgery. ${ }^{16}$ Things, of course, did not rest here. Voltaire subsequently entered the fray against Maupertuis, and the episode ended with inconclusive results, though it proved, if anything, that very great men could make great fools of themselves.

The significance of these struggles in terms of the Lockean philosophy, however, was far ranging. Wolff's prestige was seriously questioned within and without the Academy. But as long as Maupertuis was president (1746-59) the Newtonians had the upper hand; and this domination continued as long as the foreign element held the reins of power.

The Wolffian system, then, was subjected to prolonged and intensive critiques in the 1750's and 1760's. Even the most faithful disciples of Wolff, most notably Alexander Baumgarten (1714-62), G. F. Meier (1718-77), and Martin Knutzen (1720-56), began to transform their

preciate sense phenomena, but retained a great deal of their Leibniz-Wolff heritage. In some ways they advanced beyond either Locke or Leibniz to Kant's point of view. Both attacked Wolff in the Academy for his views on natural science, not for his other philosophic efforts.

${ }^{15}$ The exact text of the 1747 question reads as follows: "On demande, qu'en commençant par exposer d'une manière exacte et nette la doctrine des Monades, on examine si d'un côté elles peuvent être solidement réfutées et détruites par des arguments sans réplique; ou si de l'autre on est en état, après avoir prouvé les Monades, d'en déduire une explication intelligible des principaux phénomènes de l'Univers, et en particulier de l'origine et du mouvement des corps."

${ }^{16}$ Maupertuis' behavior made a very unfavorable impression on the Academy. To judge as a forgery a letter it had never seen in the original is not exactly sound scientific procedure. Maupertuis' victory was pyrrhic: apart from arousing the ire of the Leibnizeans within and without the Academy, Maupertuis soon had to reckon with Voltaire, who devastated him with his polemical prowess. 
master's system by laying greater emphasis on its empirical and practical aspects. Wolff himself had always insisted that philosophy must not be separated from the practical world, and he had followed up this conviction by paying due respect to empirical elements in his psychology and epistemology. This explains why his rationalism appeared as two-dimensional. ${ }^{17}$ All objects, Wolff said, should be viewed in terms of immutable as well as of probable truths - that is to say, for each field of reality there exists a knowledge of metaphysical concepts and of empirical facts. The two dimensions were to complement each other, though Wolff clearly thought the metaphysical of greater validity. Still, he was never tired of repeating that there are two ways of knowing: by experience and by reason. In psychology, for example, we must proceed in two ways, using a rationalistic psychology to discover the metaphysical concepts of the soul and an empirical psychology to prove their factuality.

In practice, Wolff was unable to maintain a radical dualism of two separate ways of knowing. ${ }^{18}$ The result of his endeavor to develop a rationalistic epistemology based on empirical foundations was that his rationalism was frequently at odds with his empiricism. This was most notorious in his psychology, and proved to be a source of embarrassment to his disciples.

These weaknesses were noted by Wolff's opponents, who promptly exploited the concessions he had made to empiricism. In the 1760's his system was slowly transformed into a kind of popular eclecticism. ${ }^{19}$ The following developments contributed toward the dilution of Wolffian rationalism: (1) his rationalistic epistemology became overshadowed by the concessions he had made to empiricism, (2) his scholastic mode of philosophizing was abandoned in favor of more informal modes of argumentation, and (3) his rigorous analytic-synthetic method was replaced by one of common sense or "sound reasoning."

III. The breakdown of Wolffian rationalism gave Locke a new, though not a permanent, lease on life in Germany. For approximately two decades (1755-75) a group of men, generally referred to as Popular Philosophers (Popularphilosophen), embraced distinctly empirical modes of thought. They admired Locke's reasonableness, his emphasis on sense experience, and his informal style of philosophizing. Their ideal, perhaps best expressed in J. J. Engel's work, "Der Philosoph für die Welt," was the gentleman scholar who wrote philosophy during his "idle and heavy hours." These "philosophers of the world" believed in man's reasonableness and his eventual perfection. They taught their generation that this is the best of all possible worlds, that reason will

${ }^{17}$ Wilhelm Windelband, Lehrbuch der Geschichte der Philosophie (Tübingen, 1957), 395.

${ }^{18}$ Lewis White Beck, Early German Philosophy, Kant and his Predecessors (Cambridge, Mass., 1969), 267.

${ }^{19} \mathrm{Gustav}$ Zart, Einfluss der Englischen Philosophen, op. cit., 72. 
gradually conquer superstition and ignorance, and that God has ordered the world in such a way as to increase happiness among all righteous men. It was a naive and, at times, trivial credo which the Popular Philosophers taught. ${ }^{20}$

Locke's ideas, then, were studied with renewed interest around midcentury by a group of littérateurs known as Popular Philosophers. His religious ideas were taken up by a group within Popular Philosophy which is often called Neologian, while his educational theories were greatly admired by that party within Popular Philosophy which styled itself "Philanthropinist." Finally, some of his ideas influenced a third party within Popular Philosophy-the so-called German empiricists. Though Locke was studied with great interest by these men, and was often cited approvingly, there is no evidence to suggest that the Popular Philosophers were Lockean.

The neological movement, comprising such figures as Johann Friedrich Wilhelm Jerusalem (1709-89), August Friedrich Wilhelm Sack (1703-86), Joachim Spalding (1714-1804), Gotthilf Samuel Steinbart (1738-1800), and Johann August Eberhard (1739-1809), was at one with Locke on the simplicity, reasonableness, and, above all, humaneness of Christianity. The Neologians also shared Locke's aversion to dogmatic systems. At the same time, practically all Neologians disliked Locke's overly rationalistic theology, and rightly perceived that it would lead to a sterile and impersonal deism. The Neologians were greatly influenced by the emotional tenor of German Pietism, a theological cast of mind which Locke would have rejected as another variety of "enthusiasm." Jerusalem and the German Neologians believed that religion was essentially a private experience-subjectively felt rather than objectively demonstrated. There is a sustained tone of enthusiasm and emotional fervor in German Neology which is conspicuously absent in Locke. Compared to Jerusalem, Sack, or Spalding, Locke's theology exudes the rational spirit of the banking house. Where Locke, in Leslie Stephen's words, "plods steadily through the Gospels and the Acts, accumulating proof after proof," ${ }^{21}$ the Neologians appeal steadily to the heart, to the beauty and harmony of nature, and to the certainty of subjective feeling.

The Neologians, then, shared some ideas with Locke, but went beyond Lockean rationalism to a more introspective theology. Beginning in the 1740's, and reaching its fruition in the last quarter of the century, German theology and philosophy became increasingly subjective and

\footnotetext{
${ }^{20}$ Many German historians have seized upon the shallow doctrines of the Popular Philosophers to condemn the whole Aufklärung as trivial. The Popular Philosophers were indeed trivial, but they do not represent the Aufklärung as a whole. To condemn the whole movement as "seicht" or "banausich" is to condemn Lessing, Wieland, Winckelmann, and Kant as trivial-judgments surely no one would wish to make.

${ }^{21}$ Leslie Stephen, History of English Thought in the Eighteenth Century (New York, 1962), I, 80.
} 
transcendental. The seeds of this development are clearly visible in German Neology. For this reason, one cannot equate Lockean Latitudinarianism with German Neology, in spite of several assumptions made by both. ${ }^{22}$ All in all, Locke's religious ideas were well known by German theologians, but never found widespread acceptance outside the liberal neological movement. Religious liberalism was a minority movement in Germany, limited to a rather small group of theologians, and religious orthodoxy continued to rule the greater part of the population throughout the Enlightenment. ${ }^{23}$

Locke's educational ideas, as expressed in his Some Thoughts Concerning Education (1693), were more readily accepted in Germany than his other theories. Johann Bernhard Basedow (1723-90), the founder of the liberal experimental school called the Dessau Philanthropinum, was an ardent follower of Locke. The same is true of Basedow's disciples, who are generally called the Philanthropinists. The last will and testament of the Philanthropinist movement was the great encyclopedia Allgemeine Revision des gesamten Schul-und Erziehungswesen von einer Gesellschaft praktischer Erzieher (16 vols., Hamburg, 178592). In this encyclopedia, to which most of the Philanthropinists contributed, Lockean ideas figure very prominently. The Philanthropinist movement, however, was an evanescent phenomenon, limited very much in space and time. On account of its utilitarian and anti-classical temper it did not materially affect the course of German education. The mainstream of German educational thought, even at the height of the Philanthropinist movement, was neohumanism, as represented by Gesner, Heyne, Ernesti, or Niethammer. ${ }^{24}$ Locke, to be sure, was admired for his good sense, his emphasis on doing and experiencing, and his observationalist method. At the same time, his one-sided utilitarianism, which at times amounted to rank philistinism, aroused much hostility and ultimately militated against Locke's widespread acceptance. The decline of Philanthropinism (Basedow's Philanthropinum collapsed in 1793) meant a corresponding diminution of interest in Locke. This diminishing interest in Locke's educational theories was greatly accelerated by the influx of Rousseauian ideas. The

${ }^{22}$ This misconception is most persistently pursued by Andrew Brown, "John Locke and the Religious Aufklärung," Review of Religion (Jan. 1949), 126-54.

${ }^{23}$ The literature in eighteenth-century theology is sizeable, but generally undistinguished. Some of the better studies are: G. R. Cragg, From Puritanism to the Age of Reason (Cambridge, 1966) and The Church and the Age of Reason, 1648-1789 (New York, 1961); Karl Aner, Die Theologie der Lessingzeit (Hildesheim, 1961); F. W. Kantzenbach, Protestantisches Christentum im Zeitalter der Aufklarung (Güterloh, 1965); and Wolfgang Philipp, Das Werden der Aufklärung in theologiegeschichtlicher Sicht (1957).

${ }^{24}$ For the role of education in eighteenth-century Germany: Karl Biedermann, Deutschland im 18. Jahrhundert, 2 vols. (Leipzig, 1854-80); W. H. Bruford, Germany in the Eighteenth Century, The Social Background of the Literary Revival (Cambridge, 1965); Oskar Lehmann, Die deutschen moralischen Wochenschriften des achtzehnten 
last two decades of the eighteenth century in Germany were dominated by Rousseau, who overshadowed all other foreign philosophers, and did so both in the popularity and in the long-range impact of his ideas.

For want of a better word, the men in Germany who came to the defense of Locke's philosophy may be called empiricists. The largest number of these Lockean admirers came from the University of Göttingen, where sober positivism sustained most academic disciplines. The most prominent Göttingen empiricists were Johann Heinrich Feder (1740-1821) and Christoph Meiners (1747-1810). In addition, there were Gottlob August Tittel (1739-1816), and Johann Friedrich Flatt (1759-1821), who sympathized with the position of Feder and Meiners. Today, their names have been forgotten and their works gather dust in a few German university libraries. There is a good reason for this. These empiricists were not only shallow and unsystematic, but engaged in such a feebleminded opposition to Kant that they lost the support of the younger generation of German philosophers. ${ }^{25}$ The same fate befell other German empiricists, though some of them, most notably Dietrich Tiedemann (1748-1803) and Johann Nicolaus Tetens (1738-1807), have been treated more charitably by posterity.

The striking thing about the German empiricists was their unusual philosophic orientation. Since they were all educated in the LeibnizWolff school of philosophy, they found it exceedingly difficult to accept English empiricism in its entirety. Most German empiricists did not, like their English or French counterparts, advance beyond Locke to a monistic interpretation of psychic phenomena. Except for such sensationalists as Johann Christian Lossius (1743-1813) or Karl Franz von Irwing (1728-1801), they refused to wipe out the Lockean distinction between sensation and reflection. The mind, they held, was far more than a mere heap or collection of perceptions-a receptacle of discrete atoms, fortuitously combined by the laws of association. To be sure, they often used mechanical metaphors, but they remained loyal to the idealist conception of the soul as both container and producer of ideas. Behind their refusal to dispense with the reflective faculty in man lurked a deep-seated philosophic conscience inherited from Leibniz. ${ }^{26}$ Try as they might, the German empiricists could not abandon the Leibniz-

Jahrhunderts als pädagogische Reformschriften (Leipzig, 1893); Friedrich Paulsen, Geschichte des gelehrten Unterrichts, 2 vols. (Leipzig, 1896), and Das deutsche Bildungswesen in seiner geschichtlichen Entwicklung (Leipzig, 1909).

${ }^{25}$ This feeble-minded opposition to Kant is especially obvious in the Philosophische Bibliothek (1788-91), a philosophical journal founded and edited by Meiners and Feder.

${ }^{26}$ It has not been sufficiently stressed that there was a Leibnizean Renaissance in the late 1760's and the 1770's, following the publication of Leibniz's Nouveaux Essais (1765). This Leibniz Renaissance was a very real and deeply-felt phenomenon, determining the future course of German history. Cf. Max Wundt, Die deutsche Schulphilosophie im Zeitalter der Aufklärung, op. cit., $317 \mathrm{ff}$. 
Wolff model of a unifying, holistic, and creative soul. Indeed, they often criticized Locke for minimizing the dynamic role played by the mind in producing ideas.

This stout-hearted defense of an autonomous soul was characteristic not only of German empiricism, but of German philosophy in general. Superficially, the history of German philosophy after 1750 appears as a struggle between two one-sided views of the mind: the innate model of Leibniz and the cash-register model expounded by English and French sensationalists. Strictly speaking, this impression is false. Not even the German empiricists could endorse the materialistic view of the mind. Of course, the German empiricists rejected Leibniz's theory of the self-sufficient monad, which they unanimously regarded as scientifically untenable. The external world, they insisted, simply could not be separated from the ego, and consequently had to be allowed to participate in consciousness. Between the ego and the world there is a constant interrelationship. Yet this relationship-and here the German empiricists refused to follow their English counterparts-is not a onesided affair, beginning and ending in sensation. Even if the material of thought is conveyed to the mind via the senses, it must still be registered, compared, united, classified-in short, transformed-by the mind itself. In processing the data of the senses, the mind imposes its own character upon them; and in so doing, displays its autonomy and self-activity.

We have here, by the German empiricists themselves, a reaffirmation of the rationalistic dictum that the senses must be intellectualized. In addition, we find that the German empiricists denied the converse, namely, that the intellect must be sensualized. Nothing is in the intellect, Locke had said, which has not previously been in the senses-to which Leibniz added the proviso "Except for the intellect itself." This celebrated statement, along with the Leibnizean caveat, now assumed renewed significance. Granted that all of our knowledge begins with experience, granted, further, that it must justify itself in experiential terms - the fact still remains that it must be validated by certain innate faculties of the mind which are transcendent in character. ${ }^{27}$

In their attempts to safeguard the spontaneous, autonomous, and, in a sense, the transcendental nature of the soul, while at the same time embracing the empiricist argument, the German empiricists clearly reveal their ambiguous position. They wanted very much to be empiricists in the English tradition. They hoped to treat the mind according to strict empirical laws, as set forth in Locke's Essay Concerning Human Understanding or in Newton's Opticks. Yet, shuddering at the implied consequences - the example of David Hume's radical empiricism being ever present to their eyes-they recoiled to a variety of rationalistic

${ }^{27}$ This active and creative dimension of the soul is especially emphasized by Tetens, as when he said that "die Seele kann nicht nur ihre Vorstellungen stellen und ordnen, 
positions. We have the curious spectacle, then, of a number of German empiricists being attracted to English philosophy, while at the same time holding fast to German idealism. Not even Tetens, the supposed "German Locke," could accept English empiricism in its entirety, as his search for a "transcendental" knowledge reveals. In a key passage, Tetens epitomizes this unique position of German empiricism by saying that:

The British philosophers may serve as a model in the field of empirical observation, but certainly not in speculative philosophy. ... It seems to me that our Leibniz has fathomed the human mind and its activities, especially in respect to transcendental knowledge, to a far greater degree of depth, accuracy, and clarity than the conscientious observationalist John Locke. ${ }^{28}$

Locke was not only a philosopher, but a major political ideologue. In point of fact, he is commonly called the founder of modern liberalism, a theory which is supposed to have been social dynamite in Western Europe and America. Yet, in Germany his political philosophy was greeted with universal insouciance-both by those who sympathized with his general philosophic outlook and those who did not. What accounts for this widespread lack of interest in Locke's political philosophy? One way to account for it is to recall that the typical form of government in eighteenth-century Germany was royal absolutism. With few exceptions, political thinkers glorified the authoritarian structure of society which prevailed everywhere. They owed their very existence to this order and consequently settled for a policy of splendid isolation as far as the world of politics was concerned. Intimidated by power, they preferred to study subjects which were not laden with political significance. The socio-economic context, then, explains in large part why they took so little interest in Locke's political writings. If any English political theorist commanded much respect in eighteenth-century Germany, it was Thomas Hobbes, not John Locke.

We have seen that Locke exerted little influence in Germany until the mid-eighteenth century, when his theories were studied with renewed interest by the Popular Philosophers-by the Neologians, the Philanthropinists, and the German empiricists. But it cannot be maintained, on that account, that the Popular Philosophers were Lockeans. Nor can it be maintained that renewed interest in Locke and English ideas turned most German philosophes into Anglomaniacs. ${ }^{29}$ It would

wie der Aufseher über eine Gallerie die Bilder, sondern sie ist selbst Mahler und erfindet und verfertiget neue Gemälde." J. N. Tetens, Philosophische Versuche über die menschliche Natur und ihre Entwicklung (Leipzig, 1777), I, 107.

${ }^{28}$ Tetens, Über die allgemeine speculativische Philosophie (Bützow, 1775), 91.

${ }^{29}$ The most serious offender in this respect is Peter Gay who, in his The Enlightenment, an Interpretation, 2 vols. (New York, 1966-69), overestimates the influence of English thinkers (Bacon, Newton, Locke) on the Enlightenment, and ignores the pro- 
be foolish to deny that the German philosophes were interested in English cultural life. Apart from the Popular Philosophers, many firstrate minds, such as Gotthold Ephraim Lessing (1729-81), Martin Wieland (1733-1813), Johann Joachim Winckelmann (1717-68), Moses Mendelssohn (1729-86), or Immanuel Kant (1724-1804), were interested in England and studied the works of English thinkers. But to say that the German philosophes studied English life and thought, and to say that they were Anglomaniacs, defining their own Weltanschauung in terms of English modes of thought-these are two very different contentions.

Locke's philosophy, which this essay takes as representative of English thought, ${ }^{30}$ never really left a very strong impression on the finest minds of the German Enlightenment. No one has ever seriously proposed that Winckelmann, Lessing, Wieland, Wolff, Mendelssohn, Euler, Lambert, or Kant were Lockeans. There is no evidence that Winckelmann ever read Locke or any other British empiricist. Insofar as he expressed philosophic convictions, he was idealistic and Platonic. Lessing and Wieland were greatly influenced by English literary models, but owed little to England for the sources of their world view. Lessing's Weltanschauung was Leibnizean, Wieland's was deeply rooted in ancient Stoicism and Epicureanism. The major German philosophers such as Mendelssohn, Euler, or Lambert, though placing greater emphasis on empirical elements in their systems, remained essentially loyal to the Leibniz-Wolff school. Even Tetens, the supposed "German Locke," was remarkably faithful to Leibniz-so much so, that he tried to devise a system in which Leibniz would be reconciled with English empiricism. ${ }^{31}$

IV. Except for some Popular Philosophers, there were few fullblooded Lockeans, just as there were few Anglomaniacs. Too many cultural barriers militated against the reception of English modes of thought, customs, and traditions. In the first place, Germany was wedded to French culture in such a way as to make intensive concern with English ideas very difficult. ${ }^{32}$ Throughout most of the eighteenth

found persistence of such other national traditions as that of the German Enlightenment led by Leibniz.

${ }^{30}$ Leslie Stephen writes that "Locke strikes, in all subjects of which he treats, the keynote of English speculation in the eighteenth century." Leslie Stephen, History of English Thought in the Eighteenth Century, op. cit., 79.

${ }^{31}$ This view is also shared by Wilhelm Uebele, who sees Tetens as a mediator between Leibniz and Locke. Wilhelm Uebele, Johann Nicolaus Tetens nach seiner Gesamtentwicklung betrachtet, mit besonderer Berücksichtigung des Verhältnisses zu Kant (Berlin, 1912), 211.

${ }^{32}$ For the continued predominance of French culture in Germany: Karl Biedermann, Deutschland im Achtzehnten Jahrhundert, 2 vols. in 3 (Leipzig, 1854-80); Werner Kraus, ed., Die Französische Aufklärung im Spiegel der Deutschen Literatur des 18. Jahrhunderts (Berlin, 1963); Betina Strauss, La Culture française à Francfort au XVIIIe siècle (Paris, 1914); and Eduard Wechssler, "Die Auseinandersetzung des 
century French intellectual and institutional traditions predominated in Germany. In government and administration French influence continued unabated until the Revolution of 1789. Many travellers to Germany were struck by this pervasiveness of French customs. Governments, for example, were little more than French Versailles in miniature. Prussia under Frederick the Great was perhaps the most extreme case. The Prussian monarch was imbued with French culture and surrounded himself with French advisers, litterrateurs, and even tax farmers. He spoke German, as he admitted proudly, only in the manner of a coachman. His dislike of the German language was so strong that, according to one authority, he would not suffer a single German book to be placed in his library. ${ }^{33}$ Frederick's Académie des Sciences was dominated by the French, and the monarch took it as a compliment when D'Alembert informed him that "Heureusement, Sire, votre Académie des Sciences ne resemble pas au reste de la nation." 34

Admittedly, Frederick's glorification of French civilization was not equalled elsewhere in Germany. But the Prussian monarch was no exception in preferring French customs and traditions. These were as fervently studied and imitated as they were in the seventeenth century. Christian Thomasius, often called the father of the German Enlightenment, urged his fellow Germans as early as 1687 to become more civilized by imitating French manners. ${ }^{35}$ His recommendation was repeated by many other illustrious Germans, most notably by the classicist Gottsched, who epitomized current feelings by his famous remark, "What the Greeks were to the Romans, the French are to us." 36

Between English and German modes of thought, therefore, stood the sum of French ideas which Germany had inherited from the seventeenth century - the period of her greatest dependence on France. The most visible sign of this influence, apart from the factors already mentioned, was the predominance of the French language. This accounts, in no small measure, for the popularity of French literature in Germany. Leipzig book catalogues reveal that French titles were as numerous as German ones. Newly published French books were generally translated into German during the very year they appeared in French print. ${ }^{37}$

Now the impact of French culture revealed itself in two directions:

deutschen Geistes mit der französischen Aufklärung," Deutsche Vierteljahresschrift für Literaturwissenschaft und Geistesgeschichte, I, 613-35.

${ }^{33}$ Biedermann, Deutschland im Achzehnten Jahrhundert, II, 236.

${ }^{34}$ Adolf Harnack, Geschichte der Königlich Preussischen Akademie, I, 362.

${ }^{35}$ Discurs, welcher Gestalt man denen Franzosen im gemeinen Leben und Wandel nachahmen solle.

${ }^{36}$ Quoted by Albert Köster, Die deutsche Literatur der Aufklärungszeit (Heidelberg, 1925), 10.

${ }^{37}$ Werner Kraus, ed., Die Französische Aufklärung im Spiegel der deutschen Literatur des 18. Jahrhunderts, CXXXIII. 
in a rationalistic philosophy and a classicistic literature. Both tendencies, reinforced by native traditions, dominated German cultural life until at least 1760 . The reactions against these movements in the 1770's was largely nationalistic and owed little, except, perhaps, in literature, to English modes of thought. ${ }^{38}$

French rationalism, which found a favorable reception in Germany, was not very conducive to Lockean empiricism. There is no doubt that Descartes enjoyed far greater prestige than Locke in Germany during the first half of the century. The man who introduced Cartesianism into Germany was Christian Wolff. The complementary nature of Wolffianism and Cartesianism has been much neglected. ${ }^{39}$ Both agreed that sense experience represents a lower form of knowledge, that emotional states distort conceptual thought, and that the mathematical method must be made the touchstone of philosophic certainty. Both tended, in addition, to denigrate the kind of experimental science which begins with individual facts and rises, by degrees, to general concepts and axioms. Instead, they favored a priori constructions to which facts were assumed to conform.

Several other factors commended Descartes to the Wolffians. His defense of innate ideas against nominalism and sense experience fitted in well with German school philosophy. The same was true, though to a lesser extent, of the mind-body dualism and the rationalistic form of theology. However, Descartes' mechanism enjoyed far less popularity, owing to the fact that modern science replaced the qualitative medieval ideology of science later in Germany than elsewhere in Europe. ${ }^{40}$ This explains why French materialism, as expounded by Holbach or La Mettrie, was regarded in Germany with unmitigated horror.

A far more persistent stumbling block against English thought was the national element in German philosophy. Two things, often complementary, checked the growth of Locke and English empiricism: the first was the multi-dimensional philosophy of Leibniz; the second, the mystical-idealistic strain in German thought.

The philosophy of Leibniz owed its strength to the way in which it affected the German mind in the eighteenth century. During the first half of the century it appeared in all its scholastic splendor, thanks to the efforts of Wolff. When Wolff's influence declined, and Lockean empiricism penetrated Germany, the other part of Leibniz's philosophy

${ }^{38}$ Those who turned against French rationalism in the 1770's, the so-called Stürmer und Dränger, found much support in English writers: Percy, Ossian, Milton, Young, and Shakespeare. In no way, however, can it be argued that these English writers precipitated the movement known as Sturm und Drang.

${ }^{39}$ This subject is briefly touched upon by Robert Sommer, who also notes the similarity between Descartes and Wolff. Robert Sommer, Grundzilge einer Geschichte der Deutschen Psychologie und Aesthetik, von Wolff-Baumgarten bis Kant-Schiller (Wuirzburg, 1892), 6ff.

${ }^{40}$ Lewis White Beck, Early German Philosophy, op. cit., 182. 
rose to the surface. This was the dynamic, evolutionary aspect of Leibniz, so long ignored by Wolff. Thus, when Wolff's prestige waned, Leibniz's philosophy was essentially unaffected. In 1765 Leibniz's Nouveaux Essais sur l'entendement humain was published for the first time. It came at a most opportune moment. Being a subtle point by point refutation of Locke's Essay Concerning Human Understanding, it did much to check the incipient growth of Lockean empiricism. The result of this Leibnizean Renaissance was that very few German philosophers subscribed to the varieties of English empiricism. The socalled German empiricists-Feder, Irwing, Tiedemann, or Tetens-are almost unknown today.

There is an additional consequence of the Nouveaux Essais which has not received sufficient notice, and that is its impact on German literature. When abstract rationalism broke down in the 1760's, it was largely owing to the influence of Leibniz. Leibniz revitalized German literature by stressing the unconscious elements of the soul and by denying the Wolffian dictum that experience and reason are different sources of knowledge. Thus the liberation of sensuality in German literature owes as much to Leibniz as to foreign sources (Rousseau, Diderot, Locke). Foreign influences merely reinforced a movement which had developed on native German soil (Leibniz, Pietism, Empfindsamkeit).

Leibniz was, of course, only part of a tradition in German thought dating back to Paracelsus and Meister Eckhart, the mystical-idealistic tradition, which neither scholasticism nor modern physical science could suppress. When Newtonian science, of which Locke was the philosophic spokesman, appeared to conquer all other modes of thought, the idealistic tendency in Germany gained a new lease on life. Its chief task in the eighteenth century was to develop a qualitative ideology of science so that belief in the spiritual elements in man and nature could be preserved. ${ }^{41}$ Most German philosophers were appalled by the mechanistic view of science because it threatened to reduce man to little more than a machine. When Goethe and his fellow students read Holbach's Système de la nature, they were struck by its morbidness and "shivered in the manner of those who are frightened by ghosts." 42

Goethe comes at the end of the Enlightenment and typifies the resentment in Germany against the Newtonian universe. Against the conception of nature as lifeless and inert he opposed a spiritualistic and vitalistic view. His inspiration was the evolutionary aspect of Leibniz's philosophy. Nature, to Leibniz, was one vast organism, teeming with vitality and life. Nature must be conceived in its evolution, in its ceaseless

${ }^{41}$ For the qualitative ideology of science in the Enlightenment: Charles C. Gillispie, The Edge of Objectivity, An Essay in the History of Scientific Ideas (Princeton, 1960).

${ }^{42}$ Goethe, Dichtung und Wahrheit, op., cit., Bk. 11. 
growth, and in its development from potentiality to actuality. The idea that the present is pregnant with the future (chargé du passé et gros de l'avenir) had very fruitful consequences in such fields as history, biology, literature, and art.

Apart from being vital or dynamic, nature is also spiritual; and as such, it contains a purpose that transcends mere matter of factness. Here is already the germ of Romanticism, and it is present in the very heart of Enlightenment philosophy.

In the final analysis, then, there was a powerful spiritualistic movement in German philosophy which stubbornly resisted the encroachments to British empiricism. This movement spiritualized nature, endowed the human soul with autonomous spontaneity, affirmed reason as the highest source of knowledge, and valued intuition more than common sense.

V. By drawing attention to the influence of Locke's thought on the German Enlightenment where it actually existed, and by indicating the kind of obstacles it encountered, this essay has, I hope, put Locke's historical importance in proper perspective. Whatever his influence was in England or France, it was negligible in Germany. His philosophic impact on the German Enlightenment was always limited by native traditions inimical to his thought. His ideas could not compete with the Leibniz-Wolff system in which all German philosophers, including the Lockean sympathizers, were educated. It is true that around midcentury and beyond Locke attracted a certain following, but those who accepted his theories were minor figures and exercised very little influence on the future course of German philosophy.

Locke was slightly more fortunate in his religious and educational theories, though, here again, native traditions always exercised a strong counterpoise. His educational and religious ideas were accepted to the extent that they harmonized with local developments. When they did, as in the case of some German Neologians and Philantropinists, the problem arises whether they directly influenced the men in question or merely reinforced what was already present. Of all the Popular Philosophers, only Steinbart, Basedow, Feder, Meiners, and Tittel were under the direct spell of Locke-hardly a very impressive group of thinkers.

What, then, remains of the claim that Locke's influence pervaded the eighteenth century with a kind of scriptural authority? Obviously, in the light of what has been said, this judgment cannot be seriously maintained in the case of Germany. No one denies that Locke was wellknown and widely read in Germany. Being a major European philosopher, how could it be otherwise? But that he materially affected the direction of German thought, both in the Age of Enlightenment and beyond, is a claim that will not hold up under close historical scrutiny.

Chapman College. 